\title{
Quality assessment of eggs from laying hens fed a mixture with lucerne protein concentrate
}

\author{
E.R. Grela ${ }^{1,3}$, K. Ognik ${ }^{2}$ A. Czech ${ }^{2}$ and J. Matras ${ }^{1}$ \\ University of Life Sciences in Lublin, ${ }^{1}$ Institute of Animal Nutrition and Bromatology, \\ ${ }^{2}$ Department of Biochemistry and Toxicology \\ Akademicka 13, 20-950 Lublin
}

KEY WORDS: lucerne, protein concentrate, fatty acids, redox, eggs, laying hens

Received: 8 May 2014

Revised: 11 July 2014

Accepted: 21 August 2014

${ }^{3}$ Corresponding author:

e-mail: ergrela@interia.pl

\begin{abstract}
The aim of this study, carried out on ISA Brown laying hens, was to determine the effect of dietary lucerne protein concentrate (LPC) on egg quality. The birds were allocated to three experimental groups, 30 birds each. The control group (C) was fed a standard feed mixture without the experimental additive. Diets of hens from groups D-1 and D-2 were supplemented with $1.5 \%$ and $3.0 \%$ of $L P C$, respectively, instead of soyabean meal. In the laying period, 40 eggs from each group were collected twice (week 33 and 53 of rearing) for evaluation of selected quality traits: specific weight of egg, eggshell colour, eggshell resistance, eggshell weight, egg yolk weight, egg yolk colour, thick albumen height, albumen quality, eggshell thickness, eggshell compactness (density), meat spots and blood spots. Egg yolks were analysed for contents of fat, total cholesterol and fatty acid composition, as well as for parameters of redox status (superoxide dismutase, catalase, hydrogen peroxides, malondialdehyde). The $1.5 \%$ and $3.0 \%$ additions of LPC increased the colour intensity of egg yolk, but at the same time, induced lipid peroxidation processes in it. The possible latter effect should be taken into account when intending to increase yolk colouration via LPC dietary supplementation. Our results show that addition of 1.5\% LPC can be recommended in feed for laying hens.
\end{abstract}

\section{Introduction}

Growing interest among consumers has been observed in recent years regarding the quality of products of animal origin, including eggs. An egg covers about $13.3 \%$ of an adult's and nearly $25 \%$ of a child's daily requirements for protein. Its high biological value has to be stressed as well. Eggs constitute a valuable component of the human diet because, in addition to protein, they contain nutrients that are essential for vital functions, i.e. lipids, vitamins and minerals. The size, colour and weight of an egg are important economic factors affecting the total inputs of poultry projects. Many studies have shown that egg composition, its nutritive value, and physicochemical properties result from the coeffects of various factors including: breed of hens, rearing conditions, storage process and culinary treatment of eggs, as well as type of feed mixture used, including feed additives (Bologa et al., 2013). Customers with quality demands have compelled producers to focus on qualitative and quantitative features of eggs to obtain high level profits. It has become necessary to search for new local feedstuff 
resources. Currently, a quest is underway for feed additives that could affect both the nutritive value of eggs and their appearance. Such effects may be expected from the use of products based on lucerne.

Lucerne protein concentrate (LPC), with about $55 \%$ crude protein and over $1200 \mathrm{mg}$ xanthophylls per kilogram, also contains many other valuable active substances: saponin glycosides $(2 \%-3 \%)$, polyphenolic compounds with oestrogenic activity (biochanin $\mathrm{A}$, daidzein), vitamins $\left(\mathrm{A}, \mathrm{B}_{1}, \mathrm{~B}_{6}, \mathrm{~B}_{12}\right.$, $\mathrm{C}, \mathrm{E}, \mathrm{K})$, provitamins ( $\beta$-carotene) and minerals (EFSA, 2009; Grela et al., 2013). The high content of xanthophylls in lucerne, and in products based on it, may increase the colour intensity of egg yolks. In addition, the presence of so many different active substances is why lucerne may exhibit multioriented pharmacological actions (Mielmann, 2013). Many of the active compounds, especially polyphenols, vitamins $\mathrm{E}, \mathrm{C}$ and $\beta$-carotene, apart from their immunomodulatory effects (Khaleel et al., 2005; Dong et al., 2007) display antioxidative properties that may attenuate oxidative processes (Aziz et al., 2006).

It was hypothesized that the addition of LPC to diets would improve the physicochemical, lipid and redox parameters of eggs.

\section{Material and methods}

\section{Animals and dietary treatments}

Experiments were conducted on eggs from ISA Brown laying hens. The birds were kept in cages located in buildings equipped in modern technological systems. The farm implemented bird identification based on wing tags with bar codes using decoders and terminals. This system significantly reduces the possibility of mistakes made during control of individual hen performance. In the entire production period, the birds were fed ad libitum, according to NRC (1994) requirements with standard full-feed mixtures (Table 1) and had free access to drinking water. The birds were allocated to three experimental groups, 30 birds each. The control group (C) was fed a standard feed mixture. The laying hens from groups D-1 and D-2 received diets with 1.5\% and $3.0 \%$, respectively, of lucerne protein concentrate (LPC; Table 2) instead of soyabean meal (Table 1). The LPC was produced by Desialis-France Luzerne. All experimental procedures were approved by the Local Ethics Committee of the Faculty of Biology and Animal Breeding at the University of Life Sciences in Lublin (Poland).

\section{Feed analysis}

The feed samples were assayed for contents of basic nutrients according to standard procedures (AOAC, 2011). Amino acids were determined by ion-exchange chromatography in a $119 \mathrm{Cl}$ Beckman amino acid analyser (Beckman Instrument Company, USA). Before analysis, the samples were subjected to acidic hydrolysis in the presence of $6 \mathrm{M} \mathrm{HCl}$, at $105^{\circ} \mathrm{C}$ for $24 \mathrm{~h}$. Sulphuric amino acids were determined separately after oxidation (Schram et al., 1954; Davies and Thomas, 1973). Tryptophan was assayed following a standard AOAC (2011) procedure.

The contents of minerals, except for phosphorus, were determined in an ASA SOLAR 939 UNICAM flame spectrophotometer (PN-EN ISO 686924), whereas the phosphorus content, spectrometrically (PN-ISO 649125).

\section{Egg measurements and analysis}

Egg production was registered in two fortnight periods (week 32-33 and 52-53). On week 33 and 53 of life, 40 eggs were collected at random from each group of hens. The eggs were subjected to egg quality assessment using electronic appliances EM (Egg Quality Measurements) from TSS QCS-II. The assessment included: egg weight, eggshell colour, thick albumen height, albumen quality, egg yolk colour, eggshell weight, eggshell thickness and eggshell density. Eggshell resistance was determined using the Instron Mini 55 (Instron, USA) apparatus. The specific weight of eggs was determined as well. The eggs were weighed twice with an accuracy of $0.01 \mathrm{~g}$ on an electronic AM 500 scale to determine their real weight (dry weight) and their weight after immersion in distilled water (wet weight). Based on these two measurements the specific weight of eggs was determined using the Haugh (1937) formula:

$$
\delta_{\mathrm{w}}=\frac{\mathrm{Q}_{1}}{\mathrm{Q}_{1}-\mathrm{Q}_{2}}
$$

where: $\delta_{\mathrm{w}}-$ specific weight, $\mathrm{Q}_{1}-$ dry weight, $\mathrm{Q}_{2}-$ wet weight.

Total fat of egg yolk for fatty acid analysis was extracted with a chloroform/methanol mixture according to Folch et al. (1957). The percentage of fatty acid methyl esters was estimated using a gas chromatography procedure on a Varian CP-3800 chromatograph. The chromatograph operating conditions for fatty acid separation were: capillary column: $\mathrm{CP}$ WAX 52CB DF $0.25 \mathrm{~mm}, 60 \mathrm{~m}$ in length; gas carrier: helium: flow rate: $1.4 \mathrm{ml} \cdot \mathrm{min}^{-1}$; column temperature $120^{\circ} \mathrm{C}$, gradually increasing by $2^{\circ} \mathrm{C} \cdot \mathrm{min}^{-1}$ up to $210^{\circ} \mathrm{C}$; determination time: $127 \mathrm{~min}$; injector 
Table 1. Ingredients and nutrient contents in feed mixtures fed in particular rearing periods of hens, $\%$

\begin{tabular}{|c|c|c|c|c|c|c|c|c|c|}
\hline \multirow[b]{2}{*}{ Indices } & \multicolumn{3}{|c|}{ Starter (week 0-9) } & \multicolumn{3}{|c|}{ Grower (week 10-17) } & \multicolumn{3}{|c|}{ Laying hens (week 18-55) } \\
\hline & C & $\begin{array}{c}D-1 \\
1.5 \% \text { LPC }\end{array}$ & $\begin{array}{c}D-2 \\
3.0 \% \text { LPC }\end{array}$ & C & $\begin{array}{c}D-1 \\
1.5 \% \text { LPC }\end{array}$ & $\begin{array}{c}\mathrm{D}-2 \\
3.0 \% \mathrm{LPC}\end{array}$ & C & $\begin{array}{c}D-1 \\
1.5 \% \text { LPC }\end{array}$ & $\begin{array}{c}D-2 \\
3.0 \% \text { LPC }\end{array}$ \\
\hline \multicolumn{10}{|l|}{ Ingredients } \\
\hline wheat & 37.2 & 37.2 & 37.2 & 36.1 & 36.1 & 36.1 & 29.0 & 29.0 & 29.0 \\
\hline maize & 19.0 & 19.0 & 19.0 & 22.0 & 22.0 & 22.0 & 20.0 & 20.0 & 20.0 \\
\hline wheat bran & 12.8 & 12.8 & 12.8 & 17.6 & 17.6 & 17.6 & 16.0 & 16.0 & 16.0 \\
\hline soyabean meal & 17.4 & 15.9 & 14.4 & 9.8 & 8.3 & 6.8 & 10.6 & 9.1 & 7.6 \\
\hline rapeseed meal & 2.6 & 2.6 & 2.6 & - & - & - & 2.0 & 2.0 & 2.0 \\
\hline sunflower meal & 1.4 & 1.4 & 1.4 & 1.0 & 1.0 & 1.0 & 2.2 & 2.2 & 2.2 \\
\hline vegetable oil & 1.1 & 1.1 & 1.1 & 0.5 & 0.5 & 0.5 & - & - & - \\
\hline dried grass & - & - & - & - & - & - & 3.0 & 3.0 & 3.0 \\
\hline LPC & - & 1.5 & 3.0 & - & 1.5 & 3.0 & - & 1.5 & 3.0 \\
\hline DDGS & 5.0 & 5.0 & 5.0 & 9.0 & 9.0 & 9.0 & 5.6 & 5.6 & 5.6 \\
\hline limestone & 1.0 & 1.0 & 1.0 & 1.5 & 1.5 & 1.5 & 8.6 & 8.6 & 8.6 \\
\hline mineral-vitamin premix & 2.5 & 2.5 & 2.5 & 2.5 & 2.5 & 2.5 & 3.0 & 3.0 & 3.0 \\
\hline \multicolumn{10}{|c|}{ Content in $1 \mathrm{~kg}$ of feed mixture } \\
\hline $\mathrm{ME}, \mathrm{kcal}^{2}$ & 2800 & 2801 & 2802 & 2840 & 2841 & 2842 & 2700 & 2701 & 2702 \\
\hline dry matter, $\%$ & 89.11 & 89.14 & 89.15 & 89.47 & 89.52 & 89.51 & 88.59 & 88.73 & 88.92 \\
\hline total protein, \% & 18.42 & 18.46 & 18.49 & 16.23 & 16.25 & 16.28 & 16.51 & 16.52 & 16.54 \\
\hline crude fat, $\%$ & 2.83 & 2.84 & 2.86 & 2.91 & 2.93 & 2.95 & 2.65 & 2.67 & 2.72 \\
\hline crude fibre, $\%$ & 3.56 & 3.55 & 3.56 & 4.87 & 4.85 & 4.87 & 4.04 & 4.03 & 4.02 \\
\hline crude ash, $\%$ & 5.12 & 5.14 & 5.15 & 5.78 & 5.84 & 5.86 & 11.21 & 11.22 & 11.24 \\
\hline lysine, \% & 0.95 & 0.95 & 0.96 & 0.71 & 0.72 & 0.73 & 0.82 & 0.82 & 0.83 \\
\hline methionine, $\%$ & 0.45 & 0.45 & 0.46 & 0.35 & 0.35 & 0.35 & 0.37 & 0.37 & 0.38 \\
\hline methionine + cystine, $\%$ & 0.72 & 0.73 & 0.74 & 0.57 & 0.58 & 0.58 & 0.65 & 0.66 & 0.67 \\
\hline tryptophan, \% & 0.18 & 0.18 & 0.18 & 0.15 & 0.15 & 0.15 & 0.16 & 0.16 & 0.16 \\
\hline arginine, $\%$ & 0.93 & 0.94 & 0.96 & 0.82 & 0.84 & 0.85 & 0.80 & 0.82 & 0.83 \\
\hline $\mathrm{Ca}, \%$ & 1.08 & 1.11 & 1.10 & 1.05 & 1.07 & 1.09 & 3.72 & 3.74 & 3.75 \\
\hline total P, $\%$ & 0.72 & 0.72 & 0.73 & 0.61 & 0.62 & 0.62 & 0.60 & 0.60 & 0.61 \\
\hline $\mathrm{Na}, \%$ & 0.15 & 0.15 & 0.15 & 0.16 & 0.16 & 0.16 & 0.15 & 0.15 & 0.15 \\
\hline $\mathrm{Fe}, \mathrm{mg}$ & 67.0 & 68.1 & 68.7 & 65.2 & 65.7 & 66.1 & 55.2 & 55.5 & 55.8 \\
\hline $\mathrm{Cu}, \mathrm{mg}$ & 5.56 & 5.62 & 5.64 & 5.51 & 5.62 & 5.65 & 5.43 & 5.44 & 5.45 \\
\hline $\mathrm{Mn}, \mathrm{mg}$ & 65.1 & 65.3 & 66.0 & 58.2 & 58.1 & 58.3 & 65.2 & 65.8 & 65.9 \\
\hline $\mathrm{Zn}, \mathrm{mg}$ & 60.4 & 60.5 & 60.8 & 60.5 & 60.8 & 60.9 & 65.1 & 65.0 & 65.2 \\
\hline
\end{tabular}

${ }^{1} \mathrm{LPC}$ - lucerne protein concentrate; ${ }^{2}$ calculated according to the equation: $\mathrm{EM}_{\mathrm{N}}\left(\mathrm{KJ} \cdot \mathrm{kg}^{-1}\right.$ of feed $)=18.03 \times \mathrm{DP}+38,83 \times \mathrm{DEE}+17,32 \times \mathrm{DNfE}$; $\mathrm{DP}$ - digestible protein, DEE - digestible ether extract, DNfE - digestible N-free extractives; $1 \mathrm{~kJ}=0.2389 \mathrm{kcal}$

Table 2. Nutrient contents in $1 \mathrm{~kg}$ of lucerne protein concentrate (LPC), dry matter basis (Grela et al., 2013)

\begin{tabular}{|c|c|c|c|c|c|}
\hline \multirow{4}{*}{$\begin{array}{l}\text { Nutrients, } g \\
\text { crude protein } \\
\text { crude fat } \\
\text { crude fibre }\end{array}$} & \multicolumn{3}{|c|}{ Macroelements, $g$} & \multicolumn{2}{|l|}{ Xantophylls, mg } \\
\hline & 552.1 & $\mathrm{Ca}$ & 32.7 & xantophylls total & $1150-1380^{1}$ \\
\hline & 108.6 & $P$ & 7.92 & lutein + zeaxanthin & $750-850^{1}$ \\
\hline & 6.3 & $\mathrm{~K}$ & 7.41 & carotene & 361 \\
\hline & & $\mathrm{Na}$ & 0.13 & & \\
\hline Amino acids & & $\mathrm{Mg}$ & 1.45 & Fatty acid profile, $g$ & \\
\hline histidine & 12.1 & & & saturated FA & 21.4 \\
\hline isoleucine & 23.3 & Microelements, $\mathrm{m}$ & & monounsaturated FA & 9.4 \\
\hline leucine & 44.9 & $\mathrm{Zn}$ & 17.33 & polyunsaturated FA & 56.6 \\
\hline lysine & 30.5 & $\mathrm{Mn}$ & 83.85 & PUFAs n-6/n-3 & 0.43 \\
\hline methionine & 10.0 & $\mathrm{Cu}$ & 10.51 & & \\
\hline phenyloalanine & 27.2 & $\mathrm{Fe}$ & 471.2 & & \\
\hline threonine & 22.2 & & & & \\
\hline tryptophan & 11.8 & \multicolumn{2}{|c|}{ Vitamins and L-canavanine, mg } & & \\
\hline valine & 29.8 & vitamin $\mathrm{E}$ & 424.7 & & \\
\hline cystein & 5.3 & vitamin $\mathrm{K}$ & 100.5 & & \\
\hline tyrosine & 20.4 & L-canavanine & 3.37 & & \\
\hline
\end{tabular}


temperature: $160^{\circ} \mathrm{C}$; detector temperature: $160^{\circ} \mathrm{C}$; other gases: hydrogen and oxygen.

Lipid quality indices, i.e. the atherogenicity index (AI) and thrombogenicity index (TI), were calculated according to the Ulbricht and Southgate (1991) equations:

$$
\begin{gathered}
\mathrm{AI}=[(4 \times \mathrm{C} 14: 0)+\mathrm{C} 16: 0] /[\mathrm{n}-6 \mathrm{PUFA}+ \\
\mathrm{n}-3 \text { PUFA + MUFA }] \\
\mathrm{TI}=[\mathrm{C} 14: 0+\mathrm{C} 16: 0+\mathrm{C} 18: 0] /[(0.5 \times \text { MUFA })+ \\
(0.5 \times \mathrm{n}-6 \mathrm{PUFA})+(3 \times \mathrm{n}-3 \mathrm{PUFA})+\mathrm{n}-3 / \mathrm{n}-6 \mathrm{UFA}] .
\end{gathered}
$$

The hypocholesterolaemic/hypercholesterolaemic ratio $(\mathrm{h} / \mathrm{H})$ was obtained according to Fernández et al. (2007):

$$
\mathrm{h} / \mathrm{H}=(\mathrm{C} 18: 1+\mathrm{C} 18: 2+\mathrm{C} 18: 3+\mathrm{C} 20: 3+\mathrm{C} 20: 4+
$$$$
\mathrm{C} 20: 5+\mathrm{C} 22: 4+\mathrm{C} 22: 5+\mathrm{C} 22: 6) /(\mathrm{C} 14: 0+\mathrm{C} 16: 0) \text {. }
$$

Extracted egg fat was assayed for total cholesterol content by the Washburn and Nix method (1974). Homogenates from egg yolks were also analysed for lipid peroxidation products, i.e. lipid peroxide content according to Gay and Gebicki (2002) and malondialdehyde according to Botsoglou et al. (1994). Malondialdehyde was determined based on the reaction of thiobarbituric acid (TBA) with lipid peroxidation end products in an acid environment and increased temperature to generate a coloured adduct. To eliminate quantities of complex series of adducts from TBA, the assay is run in the presence of inhibitors, e.g., BHT.

The activity of an antioxidative enzyme, superoxide dismutase (SOD), was determined spectrophotometrically in extracted eggs using the adrenaline method (according to Misra, in: Greenwald, 1985 ) with a modification in wavelength, i.e. at 320 $\mathrm{nm}$. This method was modified to achieve greater selectivity of intermediate reaction products at this wavelength. SOD activity was determined measuring the rate of auto-oxidation of adrenaline at $30^{\circ} \mathrm{C}$ on the basis of the increase of absorbance at $320 \mathrm{~nm}$ (which corresponds to monitoring the increase in the concentration of various products of adrenaline oxidation). The activity of catalase (CAT) was determined according to Claiborne (1985). The assay consisted of measuring the substrate (hydrogen peroxide) decomposition rate catalysed by this enzyme.

\section{Statistical analysis}

Statistical computations were carried out using STATISTICA Ver 5.1.G software (1996). For all analysed dependent variables, one-way analysis of variance, ANOVA, was conducted according to the following model:

$$
\mathrm{y}_{\mathrm{ij}}=\mu+\alpha_{i}+e_{i j}
$$

where: $\mu$ - total mean, $\alpha_{i}$ - stable effect of $i$-th additive for $i=0,1,2,3$ (for control $i=0$ ), $e_{i j}$ - random error has normal distribution $N\left(0, \sigma^{2}\right)$.

\section{Results}

Average egg production (EP) during the study equalled $92 \%$. No significant differences between groups or terms of study were found (Table 3 ). The physicochemical parameters of eggs (Table 3 ) indicated that the addition of $1.5 \%$ and $3.0 \%$ LPC to the hen feeds had no effect on the quality traits of the eggs. In turn, the study demonstrated a significant increase in the yolk colour intensity of eggs laid by hens receiving feed mixtures with $1.5 \%$ and $3.0 \%$ LPC, i.e. increases by 1.57 pts (D-1) and 1.2 pts (D-2), respectively, compared with the control group, in which egg yolk colour was assessed at 7.06 pts in the La'Roche's scale.

The analysis of egg yolks (Table 4) did not reveal any significant effect of LPC on their fat and cholesterol contents. The supplement also did not significantly influence the fatty acid profile of egg yolks, with exception of a increased n-6 PUFA content. This increase resulted in a higher $(P \leq 0.05)$ n-6/n-3 ratio in comparison with the control (Table 5). These dependencies were observed in the yolk fat of eggs collected both in week 33 as well as in week 53 of rearing.

Analysis of the mean level of $\mathrm{H}_{2} \mathrm{O}_{2}$ demonstrated its significant increase in yolks of eggs from hens fed mixtures containing both $1.5 \%$ and $3.0 \%$ LPC. In eggs from group D-1 (1.5\% LPC), the concentration of $\mathrm{H}_{2} \mathrm{O}_{2}$ increased by $24 \%$, whereas in those from group D-2 (3.0\% LPC), by as much as $35 \%$, compared with control eggs (Table 6). This correlation was observed in egg yolks collected both in week 33 and week 53 of life. The eggs of the laying hens fed the diets enriched both with $1.5 \%$ or $3.0 \%$ LPC were, additionally, characteristic because of their significantly higher level of the end product of lipid peroxidation, i.e. malondialdehyde (MDA): by $35 \%$ in group D-1 and by $50 \%$ in group D-2 in comparison with the control. These eggs also showed considerable $(P \leq 0.05)$ suppression of catalase activity compared with control eggs (Table 6). 
Table 3. Egg production and their selected quality traits (mean \pm SD) in two periods of study

\begin{tabular}{|c|c|c|c|c|c|c|c|c|c|c|}
\hline \multirow{2}{*}{ Traits } & & \multicolumn{3}{|c|}{ Period I (week 33) } & \multicolumn{3}{|c|}{ Period II (week 53) } & \multicolumn{3}{|c|}{ Average for particular groups } \\
\hline & & $\mathrm{C}$ & D-1 & $\mathrm{D}-2$ & $\mathrm{C}$ & D-1 & D-2 & $\bar{C}$ & D-1 & D-2 \\
\hline \multirow[t]{2}{*}{$\overline{E P}, \%$} & $\bar{x}$ & 91.4 & 92.3 & 91.6 & 92.2 & 92.7 & 92.1 & 91.8 & 92.5 & 91.9 \\
\hline & SD & 5.74 & 5.65 & 6.42 & 7.25 & 6.99 & 6.95 & 6.14 & 6.78 & 6.49 \\
\hline \multirow[t]{2}{*}{$E W, g$} & $\bar{x}$ & 59.2 & 59.5 & 58.8 & 59.3 & 59.8 & 59.1 & 59.2 & 59.6 & 58.9 \\
\hline & SD & 3.72 & 4.59 & 4.20 & 3.98 & 3.99 & 3.54 & 3.84 & 4.23 & 3.78 \\
\hline \multirow[t]{2}{*}{$\mathrm{SEW}, \mathrm{g} \cdot \mathrm{cm}^{-3}$} & $\bar{x}$ & 1.106 & 1.103 & 1.103 & 1.105 & 1.104 & 1.106 & 1.105 & 1.104 & 1.105 \\
\hline & SD & 0.005 & 0.005 & 0.006 & 0.005 & 0.005 & 0.004 & 0.005 & 0.005 & 0.005 \\
\hline \multirow{2}{*}{ ESC, pts } & $\bar{x}$ & 54.0 & 57.8 & 56.9 & 49.0 & 55.5 & 51.6 & 51.5 & 56.6 & 53.3 \\
\hline & SD & 8.48 & 7.00 & 7.48 & 7.24 & 8.57 & 6.67 & 7.94 & 7.72 & 7.21 \\
\hline \multirow[t]{2}{*}{ ESR, N } & $\bar{x}$ & 40.8 & 39.8 & 41.0 & 39.3 & 40.3 & 41.5 & 40.05 & 40.05 & 41.2 \\
\hline & SD & 6.12 & 6.79 & 6.05 & 7.89 & 7.53 & 6.57 & 6.97 & 6.65 & 6.23 \\
\hline \multirow{2}{*}{ ESW, g } & $\bar{x}$ & 7.1 & 7.1 & 7.0 & 7.0 & 6.8 & 6.9 & 7.05 & 6.95 & 6.97 \\
\hline & SD & 0.45 & 0.58 & 0.54 & 0.53 & 0.60 & 0.49 & 0.51 & 0.59 & 0.51 \\
\hline \multirow[t]{2}{*}{ EYW, g } & $\bar{x}$ & 14.9 & 15.7 & 15.1 & 15.9 & 16.1 & 15.5 & 15.6 & 15.9 & 15.4 \\
\hline & $S D$ & 1.22 & 1.33 & 1.05 & 1.28 & 1.16 & 1.23 & 1.25 & 1.21 & 1.13 \\
\hline \multirow[t]{2}{*}{ EYC, pts } & $\bar{x}$ & 7.1 & 8.2 & 7.8 & 7.0 & 9.0 & 8.7 & $7.06^{b}$ & $8.63^{a}$ & $8.26^{a}$ \\
\hline & SD & 1.13 & 0.75 & 1.01 & 1.12 & 0.64 & 0.83 & 1.04 & 0.68 & 0.88 \\
\hline \multirow[t]{2}{*}{$\mathrm{TAH}, \mathrm{mm}$} & $\bar{x}$ & 5.4 & 5.5 & 5.4 & 5.3 & 5.9 & 5.5 & 5.35 & 5.75 & 5.44 \\
\hline & SD & 1.11 & 1.63 & 0.97 & 1.22 & 1.52 & 1.22 & 1.16 & 1.41 & 1.12 \\
\hline \multirow[t]{2}{*}{$\mathrm{AQ}, \mathrm{Hu}$} & $\bar{x}$ & 77.3 & 71.1 & 71.5 & 68.8 & 74.6 & 71.3 & 71.6 & 73.4 & 71.3 \\
\hline & SD & 8.81 & 7.26 & 9.26 & 7.61 & 6.48 & 8.59 & 8.25 & 6.91 & 8.98 \\
\hline \multirow[t]{2}{*}{$\mathrm{EST}, \mu \mathrm{m}$} & $\bar{x}$ & 344 & 339 & 332 & 314 & 315 & 320 & 324 & 323 & 324 \\
\hline & SD & 28.7 & 22.27 & 29.6 & 27.5 & 26.3 & 27.1 & 27.9 & 24.5 & 28.3 \\
\hline \multirow[t]{2}{*}{$\mathrm{ESD}, \mathrm{mg} \cdot \mathrm{cm}^{-2}$} & $\bar{x}$ & 101 & 99 & 98 & 97 & 96 & 97 & 98.5 & 97.5 & 97.5 \\
\hline & $S D$ & 5.72 & 6.23 & 6.74 & 5.91 & 6.72 & 5.16 & 5.85 & 6.39 & 5.74 \\
\hline
\end{tabular}

EP - egg production, EW - egg weight, SEW - specific egg weight, ESC - eggshell colour, ESR - eggshell resistance, ESW - eggshell weight, EYW - egg yolk weight, EYC - egg yolk colour, TAH - thick albumen height, AQ - albumen quality, EST - eggshell thickness, ESDS - eggshell density; ${ }^{a, b}$ means with different superscipts within a row are significantly different at $P \leq 0.05$

Table 4. Contents of fat and total cholesterol in egg yolk (mean \pm SD) in two periods of study

\begin{tabular}{|c|c|c|c|c|c|c|c|c|c|c|}
\hline \multirow{2}{*}{\multicolumn{2}{|c|}{ Indices }} & \multicolumn{3}{|c|}{ Period I (33 week) } & \multicolumn{3}{|c|}{ Period II (53 week) } & \multicolumn{3}{|c|}{ Average for particular groups } \\
\hline & & C & D-1 & D-2 & $\bar{C}$ & D-1 & D-2 & $\mathrm{C}$ & D-1 & D-2 \\
\hline \multirow[t]{2}{*}{ Fat, $\mathrm{mg} \cdot \mathrm{g}^{-1}$} & $x$ & 315.4 & 317.5 & 320.1 & 321.4 & 314.6 & 317.5 & 318.4 & 316.1 & 318.8 \\
\hline & SD & 2.35 & 3.14 & 2.08 & 1.89 & 2.39 & 2.44 & 2.14 & 2.81 & 2.23 \\
\hline \multirow[t]{2}{*}{ Cholesterol, $\mathrm{mg} \cdot \mathrm{g}^{-1}$} & & 14.36 & 13.88 & 13.94 & 15.21 & 13.87 & 14.28 & 14.73 & 13.87 & 14.11 \\
\hline & SD & 0.38 & 0.29 & 0.18 & 0.47 & 0.41 & 0.32 & 0.43 & 0.34 & 0.27 \\
\hline
\end{tabular}

Table 5. Fatty acid profile (\%) and some lipid quality indices in egg yolk (mean \pm SD) in two periods of study

\begin{tabular}{|c|c|c|c|c|c|c|c|c|c|c|}
\hline \multirow{2}{*}{ Indices } & & \multicolumn{3}{|c|}{ Period I (33 week) } & \multicolumn{3}{|c|}{ Period II (53 week) } & \multicolumn{3}{|c|}{ Average for particular groups } \\
\hline & & $\bar{C}$ & D-1 & D-2 & $\bar{C}$ & D-1 & D-2 & $\bar{C}$ & D-1 & $\mathrm{D}-2$ \\
\hline \multirow[t]{2}{*}{$\overline{S F A}$} & $\bar{x}$ & 33.70 & 33.56 & 34.60 & 34.54 & 33.96 & 35.84 & 34.12 & 33.76 & 35.22 \\
\hline & SD & 0.71 & 0.78 & 0.77 & 1.51 & 0.96 & 1.34 & 1.18 & 0.82 & 1.12 \\
\hline \multirow[t]{2}{*}{ MUFA } & $\bar{x}$ & 49.89 & 49.67 & 49.12 & 49.65 & 50.07 & 48.92 & 49.77 & 49.87 & 49.02 \\
\hline & SD & 1.49 & 4.14 & 1.71 & 1.54 & 1.96 & 1.47 & 1.38 & 2.26 & 1.53 \\
\hline \multirow[t]{2}{*}{ PUFA } & $\bar{x}$ & 16.07 & 15.11 & 15.77 & 15.46 & 15.41 & 14.93 & 15.77 & 15.26 & 15.35 \\
\hline & SD & 1.18 & 2.05 & 0.48 & 0.68 & 1.04 & 0.84 & 0.95 & 1.48 & 0.54 \\
\hline \multirow[t]{2}{*}{$\sum n-6 / \Sigma n-3$} & $\bar{x}$ & $15.16^{b}$ & $20.51^{a}$ & $19.28^{\mathrm{a}}$ & $16.25^{b}$ & $19.59^{a}$ & $19.53^{\mathrm{a}}$ & $15.71^{b}$ & $20.05^{a}$ & $19.41^{a}$ \\
\hline & SD & 2.05 & 1.31 & 2.21 & 1.58 & 1.36 & 1.81 & 1.82 & 1.27 & 2.01 \\
\hline \multirow[t]{2}{*}{ Al } & $\bar{x}$ & 0.40 & 0.39 & 0.42 & 0.41 & 0.39 & 0.44 & 0.41 & 0.39 & 0.43 \\
\hline & SD & 0.013 & 0.013 & 0.011 & 0.019 & 0.016 & 0.023 & 0.015 & 0.013 & 0.014 \\
\hline \multirow[t]{2}{*}{ TI } & $\bar{x}$ & 12.05 & 12.43 & 11.19 & 12.45 & 12.84 & 11.69 & 12.25 & 12.64 & 11.44 \\
\hline & $\mathrm{SD}$ & 1.25 & 1.01 & 0.62 & 1.13 & 0.75 & 1.02 & 1.14 & 0.89 & 0.83 \\
\hline \multirow[t]{2}{*}{$h / H$} & $\bar{x}$ & 2.41 & 2.46 & 2.31 & 2.27 & 2.39 & 2.14 & 2.34 & 2.43 & 2.24 \\
\hline & SD & 0.17 & 0.19 & 0.16 & 0.13 & 0.21 & 0.14 & 0.15 & 0.18 & 0.13 \\
\hline
\end{tabular}

SFA - saturated fatty acids, MUFA - monounsaturated fatty acids, PUFA - polyunsaturated fatty acids, $\mathrm{Al}$ - atherogenicity index, $\mathrm{TI}$ - thrombogenicity index, $\mathrm{h} / \mathrm{H}$ - hypocholesterolaemic/hypercholesterolaemic ratio; ${ }^{\mathrm{a}, \mathrm{b}}$ means with different superscipts within a row are significantly different at $P \leq 0.05$ 
Table 6. Redox indices in egg yolk (mean \pm SD) in two periods of study

\begin{tabular}{|c|c|c|c|c|c|c|c|c|c|c|}
\hline \multirow{2}{*}{\multicolumn{2}{|c|}{ Indices }} & \multicolumn{3}{|c|}{ Period I (33 week) } & \multicolumn{3}{|c|}{ Period II (53 week) } & \multicolumn{3}{|c|}{ Average for particular groups } \\
\hline & & C & $\mathrm{D}-1$ & D-2 & $\mathrm{C}$ & $\mathrm{D}-1$ & $\mathrm{D}-2$ & $\mathrm{C}$ & D-1 & D-2 \\
\hline SOD & $\bar{x}$ & 27.5 & 28.08 & 27.5 & 25.48 & 26.72 & 26.73 & 26.49 & 27.40 & 27.11 \\
\hline$U \cdot g^{-1}$ & SD & 0.28 & 0.26 & 0.31 & 0.68 & 0.63 & 0.82 & 0.44 & 0.46 & 0.56 \\
\hline CAT & $\bar{x}$ & $34.31^{a}$ & $29.45^{b}$ & $30.56^{\mathrm{ab}}$ & $35.14^{\mathrm{a}}$ & $29.25^{b}$ & $28.14^{b}$ & $34.72^{\mathrm{a}}$ & $29.89^{b}$ & $29.07^{b}$ \\
\hline$U \cdot g^{-1}$ & SD & 5.22 & 4.41 & 4.18 & 6.22 & 4.48 & 5.27 & 5.43 & 4.44 & 4.67 \\
\hline $\mathrm{H}_{2} \mathrm{O}_{2}$ & $\bar{x}$ & $5.19^{c}$ & $6.27^{b}$ & $8.23^{a}$ & $5.63^{b}$ & $7.93^{\mathrm{a}}$ & $8.42^{\mathrm{a}}$ & $5.41^{\mathrm{c}}$ & $7.10^{\mathrm{b}}$ & $8.32^{\mathrm{a}}$ \\
\hline $\mathrm{ng}^{2} \mathrm{~g}^{-1}$ & SD & 0.45 & 0.61 & 0.67 & 0.36 & 0.47 & 0.52 & 0.41 & 0.53 & 0.64 \\
\hline MDA & $\bar{x}$ & $0.183^{b}$ & $0.262^{\mathrm{a}}$ & $0.364^{a}$ & $0.179^{b}$ & $0.299^{a}$ & $0.358^{a}$ & $0.181^{b}$ & $0.280^{a}$ & $0.361^{a}$ \\
\hline $\mathrm{ng} \cdot \mathrm{g}^{-1}$ & SD & 0.08 & 0.09 & 0.03 & 0.09 & 0.08 & 0.07 & 0.08 & 0.08 & 0.05 \\
\hline
\end{tabular}

$\mathrm{SOD}$ - superoxide dismutase, CAT - catalase, $\mathrm{H}_{2} \mathrm{O}_{2}$ - peroxides, MDA - malondialdehyde; ${ }^{\mathrm{a}, \mathrm{b}, \mathrm{c}}$ means with different superscipts within a row are significantly different at $P \leq 0.05$

\section{Discussion}

Egg yolk colour is one of the egg attributes that attract consumer interest. In our experiment, increased egg yolk colour intensity was observed in both groups of hens receiving LPC. As reported by Franchini (2007), the colour of egg yolk is influenced by many factors, e.g., by the quantity and quality of ingested feed, genotype, age and health status of hens, laying rate, or the mycotoxin level in the feed mixture. However, egg yolk colour also greatly depends on the type and content of natural or synthetic xanthophyll pigments in the feed. The pigments are absorbed in the small intestine of hens with various intensity and then accumulated in egg yolks. Consumers from different countries prefer different egg yolk colouration. Nevertheless, the most preferable is $11-12$ pts on the La'Roche scale (Nys and Sauveur, 2004). The increase in yolk colour intensity demonstrated in our study results from the high concentration of xanthophylls (e.g., lutein) in LPC added to the feeds. According to Zhang et al. (2011), canthaxantin (red pigments), which belongs to a group of xanthophylls, added in the amount of $6 \mathrm{mg}$ per $\mathrm{kg}$ of mixture, improved egg yolk colouration. Their study demonstrated that dietary supplementation with canthaxantin caused a significant increase in the colourimetric value of egg yolk measured in the La'Roche scale. Investigations by Rosa et al. (2012) with the use of canthaxantin $\left(6 \mathrm{mg} \cdot \mathrm{kg}^{-1}\right.$ diet $)$ as an additive in feed mixtures for laying hens proved that in the second week of supplementation, the colourimetric value of egg yolks increased from 9.33 to 14.67 pts in La'Roche scale. According to these authors, this difference in yolk colour remained stable over the entire 20-week experiment. Also Fredriksson et al. (2006), in their experiment on laying hens fed a diet containing a lucerne component, noted increased intensity of egg yolk colour. They claim that such a result was due to a high content of xanthophyll, including lutein and zeaxanthin in lucerne. An increase in egg yolk colour intensity by 2.3 pts in the La'Roche scale compared with the control group was also achieved by Sobczak and Marek (2012), who applied green forage from canna in laying hen diets. Investigations conducted by Laudadio and Tufarelli (2011) prove that also the addition of legumes, e.g., lupin (Lupinus albus cv. Multitalia), to diets contributes to an increased colourimetric value of egg yolk. The impact of leguminous plants (lupin) on egg yolk colour was directly linked with the presence of natural pigments (xanthophylls). The studies of other authors (Laudadio and Tufarelli, 2010) also demonstrated the positive effect of addition of papilionaceous plants (pea or bean) to feed mixtures for laying hens on the colour of egg yolk. Radwan et al. (2008) also achieved more intensive colouration of egg yolk after the addition of natural antioxidants: thyme, rosemary, oregano and turmeric, to diets for laying hens. According to these authors, this effect was attributable to the yellow pigments of turmeric.

LPC contains 2\%-3\% saponin glycosides. Many, but not all, studies have shown that saponins from different sources reduce blood cholesterol levels of animals (Francis et al., 2002). In our study, the LPC used was shown to have no effect on fat and cholesterol contents in egg yolks. These results correspond with those achieved by Nakaue et al. (1980), who reported that feeding laying hens with $10 \%$ saponin-rich, dehydrated lucerne meal did not alter yolk cholesterol contents. Sim et al. (1984) fed laying hens varying levels of a commercial sarsaponin (steroidal saponin)-rich extract from Yucca shottii and also failed to observe any significant effects on egg or serum cholesterol levels; however, they reported that the saponin product decreased feed intake and egg production. Francis et al. (2002) fed the most common commercial source of steroid saponins, and observed no effect on yolk weight or 
cholesterol content. Kaya et al. (2003) reported a similar lack of effect of Yucca shidigera in laying Japanese quail. Considering that laying hens are normally fed diets with little, if any, dietary cholesterol, the lack of effect of dietary saponins on plasma and egg yolk cholesterol concentrations is not surprising, and indicates that the hypocholesterolaemic action of these compounds may be primarily mediated via cholesterol binding in the intestine.

The presence of lipid substances (especially polyunsaturated fatty acids) in eggs may be accompanied by oxidative processes that significantly affect their quality. These processes result in the formation of peroxides and the final product - malondialdehyde (MDA). Mansoub (2011) on the basis of a study with lucerne extract administered to laying hens indicated that deposition of plant pigments into yolk made it more colourful. The enhancement in the yolk colour index is related to the stability of yellow pigments among the lipid molecules in the membrane of the yolk. Antioxidants can protect these molecules from oxidative stress. Some carotenoids in this plant, like xanthophylls, transferred into the yolk increase its yellow colour. A similar effect may be observed when maize or wheat grainbased diets are fed. In our study, the eggs laid by the hens receiving the lucerne protein concentrate were characterized by higher contents of lipid peroxidation products $\left(\mathrm{H}_{2} \mathrm{O}_{2}\right.$ and MDA), and enhanced acti-vity of catalase. These results are surprising because the applied experimental additive (LPC) contains many natural antioxidants, including xanthophylls, which should theoretically contribute to the inhibition of oxidative processes. This makes our results even more difficult to interpret because our previous studies demonstrated that both $1.5 \%$ and $3.0 \%$ additions of LPC to feed mixtures for turkey hensdecreased the concentrations of $\mathrm{H}_{2} \mathrm{O}_{2}$ and MDA in blood plasma (Czech et al., 2012). Investigations conducted on wild gulls receiving $2 \mathrm{mg}$ of added carotenoid in feed demonstrated the impact of this additive as it increased content of antioxidants in egg yolk and reduced the susceptibility of these yolks to oxidation (Blount et al., 2002). The results achieved in our study may be due to oxidation of xanthophyllic compounds, the content of which was increased in the eggs of hens receiving LPC. Often, increasing the content of low molecular weight antioxidants susceptible to oxidation may induce the opposite effect, namely pro-oxidation. Owing to the presence of double bonds in their molecule, xanthophyllic compounds easily enter into reactions with electrophilic compounds, and in the presence of oxygen and heavy metals $(\mathrm{Cu}, \mathrm{Zn}, \mathrm{Fe})$ they may undergo auto-oxidation, thus initiating an avalanche of free-radical reactions. In turn, suppressed activity of catalase in eggs laid by hens receiving a feed mixture containing LPC results from mobilization of this enzyme for an antioxidative reaction aimed at inhibiting the generation of free radicals. In turn Palozza et al. (2000), who enriched feed mixtures for laying hens with xanthophyll, reported an increase in the activity of superoxide dismutase and catalase, which indicates the stimulating effect of this additive on antioxidative status. The achieved results correspond with the opinion of Xie et al. (2008), who stated that the addition of lucerne leaves to feed mixtures for laying hens may neutralize the generation of free peroxide and hydroxyl radicals. The disparity of results may also be due to the selection of other feed components that additionally introduce other antioxidants susceptible to oxidation, as well as to different doses of antioxidative additives. Despite the oxidative effect noted in eggs of hens fed mixtures with the addition of LPC concentrate, most studies investigating the impact of natural feed additives with potential antioxidative properties (oregano, rosemary, thyme, saffron) point to the capability of these additives to diminish lipid peroxidation in eggs (Radwan et al., 2008).

\section{Conclusions}

The $1.5 \%$ or $3.0 \%$ addition of a protein concentrate from lucerne (LPC) to a feed mixture for hens increased the colour intensity of egg yolk, but induced lipid peroxidation processes in the yolk. The latter possible effect should be taken into account when intending to increase yolk colouration via LPC dietary supplementation. The results show that for laying hen production, a 1.5\% addition of LPC in the diet can be recommended.

\section{Acknowledgements}

The study was supported by the National Center of Research and Development, Poland, Project No. 12000506.

\section{References}

Andurand J., Coulmier D., Despres J.L., Rambourg J.C., 2010. Industrial extraction of proteins and pigments from alfalfa: status and prospects (in French). Innov. Agronom. 11, 147-156

AOAC, 2011. Association of Official Analytical Chemistry, Official Methods of Analysis. $18^{\text {th }}$ Edition. Gaithersburg, MA 
Aziz A.B., Grossman S., Budowski I., Ascarielli I., Bondi A., 2006. Antioxidant properties of lucerne extracts. J. Sci. Food Agric. 19, 605-608

Blount J.D., Surai P.F., Houston D.C., Møller A.P., 2002. Patterns of yolk enrichment with dietary carotenoids in gulls: the roles of pigment acquisition and utilization. Funct. Ecol. 16, 445-453

Bologa M., Pop I.M., Albu A., 2013. Research on chemical composition of chicken egg from different system of production (conventional and organic). Lucrări. Şti. Zoot. 59, 80-85

Botsoglou N.A., Fletouris D.J., Papageorgiou G.E., Vassilopoulos V.N., Mantis A.J., Trakatellis A.G., 1994. Rapid sensitive and specific thiobarbituric acid method for measuring lipid peroxidation in animal tissue, food and feed-stuff samples. J. Agr. Food Chem. 42, 1931-1937

Claiborne A., 1985. Catalase activity. In: R.A. Greenwald (Editor). Handbook of Methods for Oxygen Free Radical Research. CRC Press, Boca Raton, FL (USA), pp. 283-284

Czech A., Ognik K., Grela E.R., 2012. Efficacy of a mixture of synthetic antioxidant and protein xanthophyll alfalfa concentrate in turkey hens feeding. Arch. Geflügelkd. 76, 105-112

Davies M.G., Thomas A.J., 1973. An investigation of hydrolytic techniques for the amino acid of foodstuffs. J. Sci. Food Agric. $24,1525-1540$

Dong X.F., Gao W.W., Tong J.M., Jia H.Q., Sa R.N., Zhang Q., 2007. Effect of polysavone (alfalfa extract), on abdominal fat deposition and immunity in broiler chickens. Poultry Sci. 86, 19551959

EFSA, 2009. Opinion on the safety of 'Lucerne protein concentrate' as food. EFSA J. 997, 1-19

Fernández M., Ordóñez J.A., Cambero I., Santos C., Pin C., De la Hoz L., 2007. Fatty acid compositions of selected varieties of Spanish dry ham related to their nutritional implications. Food Chem. 9, 107-112

Folch J., Lees M., Sloane Stanley G.H., 1957. A simple method for the isolation and purification of total lipids from animal tissue. J. Biol. Chem. 226, 497-509

Franchini A., 2007. Egg quality traits of laying hens reared in organic and conventional systems. Ital. J. Anim. Sci. 6, 728-730

Francis G., Kerem Z., Makker H.P.S., Becker K., 2002. The biological action of saponins in animal systems: a review. Brit. J. Nutr. $88,587-605$

Fredriksson S., Elwinger K., Pickova J., 2006. Fatty acid and carotenoid composition of egg yolk as an effect of microalgae addition to feed formula for laying hens. Food Chem. 99, 530-537

Gay C., Gebicki J.M., 2002. Perchloric acid enhances sensitivity and reproducibility of the ferric-xylenol orange peroxide assay. Anal. Biochem. 304, 42-46

Greenwald R.A., 1985. CRC Handbook of Methods for Oxygen Radical Research. CRC Press Boca Raton, FL (USA)

Grela E.R., Pietrzak K., Kowalczuk-Vasilev E., Klebaniuk R., Borucka B., 2013. Analysis of chemical composition of protein-xanthophyll concentrate (in Polish). Przem. Chem. 92, 1484-1488

Haugh R.R., 1937. The Haugh unit for measuring egg quality. U.S. Egg Poultry Mag. 43, 552-555

Kaya S., Erdogan Z., Erdogan S., 2003. Effect of different dietary levels of Yucca schidigera powder on the performance, blood parameters, and egg yolk cholesterol of laying quails. J. Vet. Med. 50, 14-17
Khaleel A.E., Gad M.Z., El-Maraghy S.A., Hifnawy M.S., Abdel-Satter E., 2005. Study of hypocholesterolemic and antiatherosclerotic properties of Medicago sativa. J. Food Drug Anal. 13, 212-218

Laudadio V., Tufarelli V., 2010. Treated faba bean (Vicia faba var. minor) as substitute for soybean meal in diet of early phase laying hens: egg-laying performance and egg quality. Poultry Sci. 89, 2299-2303

Laudadio V., Tufarelli V., 2011. Influence of substituting dietary soyabean meal for dehulled-micronized lupin (Lupinus albus CV. Multitalia) on early phase laying hens production. Livest. Sci. 140, 184-188

Mansoub N.H., 2011. Effect of different level of lucerne extract on performance, egg quality and some blood parameters of laying hens. Ann. Biol. Res. 2, 384-388

Mielmann A., 2013. The utilisation of lucerne (Medicago sativa). Brit. Food J. 115, 590-600

Nakaue H.S., Lowry R.R., Cheeke P.R., Arscott G.H., 1980. The effect of dietary lucerne of varying saponin content on yolk cholesterol level and layer performance. Poultry Sci. 59, 2744-2748

NRC, 1994. Nutrient Requirements of Poultry. $9^{\text {th }}$ revised Edition. Washington, DC

Nys Y., Sauveur B., 2004. The nutritional value of eggs. INRA Prod. Anim. 17, 385-393

Palozza P., Calviello G., Emilia de Leo M., Serini S., Bartoli G.M., 2000. Canthaxanthin supplementation alters antioxidant enzymes and iron concentration in liver of Balb/c mice. J. Nutr. 130, 1303-1308

Radwan N.L., Hassan R.A., Qota E.M., Fayek H.M., 2008. Effect of natural antioxidant on oxidative stability of eggs and productive and reproductive performance of laying hens. Int. J. Poultry Sci. 7, 134-150

Rosa A.P., Scher A., Sorbara J.O.B., Boemo L.S., Forglarin J., Londero A., 2012. Effects of canthaxantin on the productive and reproductive performance of broiler breeders. Poultry Sci. 91, 660-666

Schram E., Moore S., Bigwood E.J., 1954. Chromatographic determination of cystine as cysteic acid. Biochem. J. 57, 33-37.

Sim J.S., Kitts W.D., Bragg D.B., 1984. Effect of dietary saponin on egg cholesterol level and laying hen performance. Can. J. Anim. Sci. 64, 977-984

Sobczak J., Marek P., 2012. The influence of green fodder of red canna (Canna $\times$ generalis) on the intensity of colour of yolks of food eggs (in Polish). Rocz. Nauk. PTZ 8, 65-72

Ulbricht T.L., Southgate D.A.T., 1991. Coronary heart disease: seven dietary factors. Lancet 338, 985-992

Washburn K.W., Nix D.F., 1974. A rapid technique for extraction of yolk cholesterol. Poultry Sci. 53, 1118-1122

Xie Z., Huang J., Xu X., Jin Z., 2008. Antioxidant activity of peptides isolated from alfalfa leaf protein hydrolysate. Food Chem. 111, 370-376

Zhang W., Zhang K.Y., Ding X.M., Bai S.P., Hernandez J.M., Yao B., Zhu Q., 2011. Influence of canthaxantin on broiler breeder reproduction, chick quality, and performance. Poultry Sci. 90, 1516-1522 